\title{
Stakeholder Perception Management of the Crisis at the Samanalawewa Hydro Power Station of Ceylon Electricity Board
}

\begin{abstract}
A. P. K. Mutunayake
Abstract: This case study is on the crisis that arose at the Samanalawewa Hydro Power Station (SWPS) of the Ceylon Electricity Board (CEB), Sri Lanka due to the massive water leakage that occurred at the right abutment of its dam in 1992 during the trial impoundment of the reservoir and the subsequent stakeholder perception management of the power station. It covers a period of 20 years commencing from 1992 and ending in 2012. The power station commenced its commercial operations in 1992 after its construction work was completed under the Samanalawewa Hydro Electric Power (SHEP) Project. Although various remedial steps were taken to arrest the leak, it continued with an average flow of $2.4 \mathrm{~m}^{3} / \mathrm{s}$. The low sustainability of the project and risks associated with the massive leakage of water downstream created a poor public perception about the Samanalawewa Hydro Power Station. Together with the staff of the Samanalawewa Hydro Electric Power Project, the management of the Samanalawewa Hydro Power Station took steps to change the perception of its stakeholders. This case study covers the successful perception management related to the SWPS.
\end{abstract}

Keywords: Perception Management, Crisis, Leak, Samanalawewa Hydro Power Stations, CEB

\section{Introduction}

The Ceylon Electricity Board (CEB) is the main power supplier to the national grid of Sri Lanka and controls all major functions of electricity generation, transmission and distribution in Sri Lanka.

The CEB is one of the largest government owned utilities in Sri Lanka and in 2011 it had 16,192 permanent employees (CEBa, 2012). In the year 2011, it had a consumer base of 4.7 million consumers which is a $4.7 \%$ growth compared to the corresponding figures in the previous year (CEBb, 2012).

In 2012, the CEB had an installed generation capacity of $2214 \mathrm{MW}$ and this was almost $2 / 3$ of the total installed capacity of the island. The total hydro power capacity of the CEB was 1357MW in 2012 (CEBb). The list of CEB owned Hydro Power Stations that have capacities over $100 \mathrm{MW}$ is given in Table 1.
Table 1 - CEB Owned Hydro Power Stations (Above 100MW)

\begin{tabular}{|c|c|c|}
\hline $\begin{array}{c}\text { Name of the } \\
\text { generating } \\
\text { plant }\end{array}$ & $\begin{array}{c}\text { No. of } \\
\text { plants } \times \\
\text { capacity in } \\
\text { MW }\end{array}$ & $\begin{array}{c}\text { Total } \\
\text { Capacit } \\
\text { y (MW) }\end{array}$ \\
\hline Victoria & $3 \times 70$ & 210 \\
\hline Kothmale & $3 \times 67$ & 201 \\
\hline $\begin{array}{l}\text { Upper } \\
\text { Kothmale }\end{array}$ & $2 \times 75$ & 150 \\
\hline Randenigala & $2 \times 61$ & 122 \\
\hline Samanalawewa & $2 \times 60$ & 120 \\
\hline New Laxapana & $2 \times 50$ & 100 \\
\hline
\end{tabular}

Source: Author prepared from CEB data

Eng. A.P.K.Mutunayake, B.Sc. Eng. (Hons) (Ruhuna), M.Eng. (Moratuwa), MBA (PIM-Sri Jayawardenepura.), CEng. MIE(SL), AMSLEMA, Mechancal Engineer, Ceylon Electricity Board 


\section{1}

Samanalawewa Hydro Electric Power Project

Samanalawewa Hydro Electric Power (SHEP) Project was intended to meet the shortage of electricity supply in Sri Lanka by constructing in the upstream of Walawe River, approximately $160 \mathrm{~km}$ southeast of Colombo (Figure 1) a reservoir-type hydroelectric power plant with a maximum output of $120 \mathrm{MW}$.

This Project was co-financed through an ODA loan from Japan and some other loans from U.K. The Project which commenced in 1986 had an estimated total cost of 60,176 million yen.

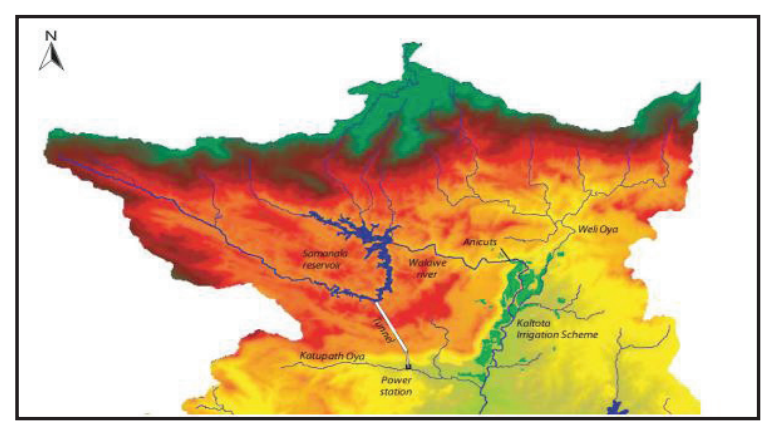

Figure 1 - SHEP Project Location in the Walawe Basin

Source: Molle et al., 2006

The Samanalwewa Hydro Power Station (SWPS) which has a 120MW (i.e. 2 × $60 \mathrm{MW}$ ) of installed capacity is the fifth largest CEB owned hydro power station. The power station commenced its commercial operations in 1992 after the completion of its construction work under the SHEP Project. The upstream view of the Samanalawewa dam and the reservoir is shown in Figure 2.

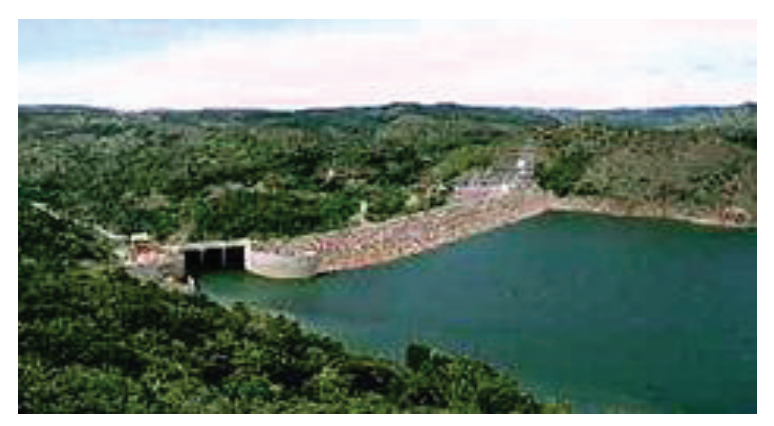

Figure 2 - Samanalawewa dam and reservoir

Source: Author

\subsection{Leak}

Geologically the project is in an area of karst within the Highland series of the Sri Lankan Precambrian complex comprised of crystalline metamorphic rocks (Laksiri, Gunathilake \& Iwao, 2005). The area has been subjected to extensive folding, faulting and hydrothermal reactions. Thus, the project area is geologically complex.

According to Laksiri et al (2005), on several occasions a number of agencies have studied the project site and conducted various detailed geological, hydrogeological and geophysical investigations. The signs of a possible leak through the right bank appeared when poor geological conditions were encountered during the construction of the dam. In response to that more investigations were carried out. During the initial trial impoundment, a small spring had appeared downstream of the partially filled reservoir, and impoundment had to be suspended (Laksiri et al, 2005).

Additionally, up to a distance of $2.5 \mathrm{~km}$ on the right bank, a flat water table had been observed responding to the river levels. As a remedial measure, a 100m-deep, 1300m-long grout curtain had been constructed, using 13,640 tons of cement, and impoundment resumed. However the leakage had increased and continued finally resulting in a land slide (Laksiri et al, 2005). Due to the massive water leakage, reservoir impoundment had been again suspended, and more detailed investigations carried out. According to the records, this had been the first such experience of CEB in the history of hydro power generation projects. Figure 3 shows the water leakage of the right bank of the Samanalawewa reservoir. 


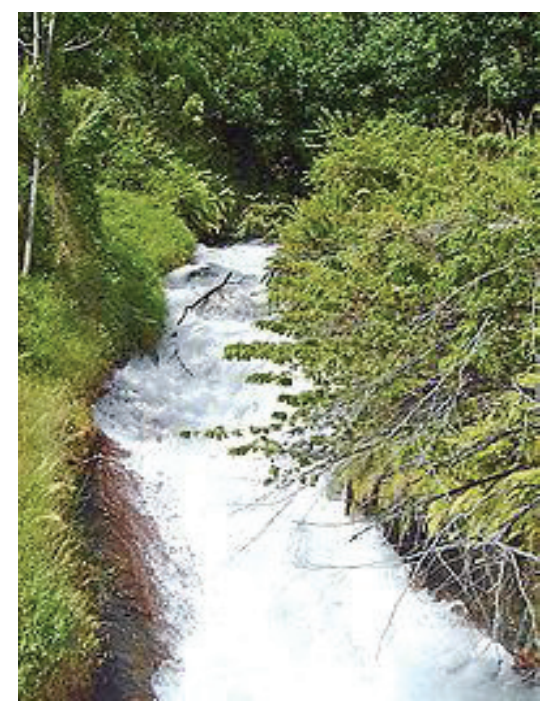

Figure 3 - Samanalawawa Leak

Source: Author

The next remediation effort consisted of installing a liner of clay over the suspected ingress zones (i.e. wet blanketing). According to Laksiri et al, 2005, even after using 50,000 $\mathrm{m} 3$ of clay, the leakage could not be stopped, although it did help to reduce groundwater pressure in the right bank.

According to the SWPS dam monitoring data, the reservoir is presently operating with a continuous uncontrolled water leakage of 2.3 to $2.4 \mathrm{~m}^{3} / \mathrm{s}$. The behavior of the leak and reservoir water levels is shown in Figure 4.

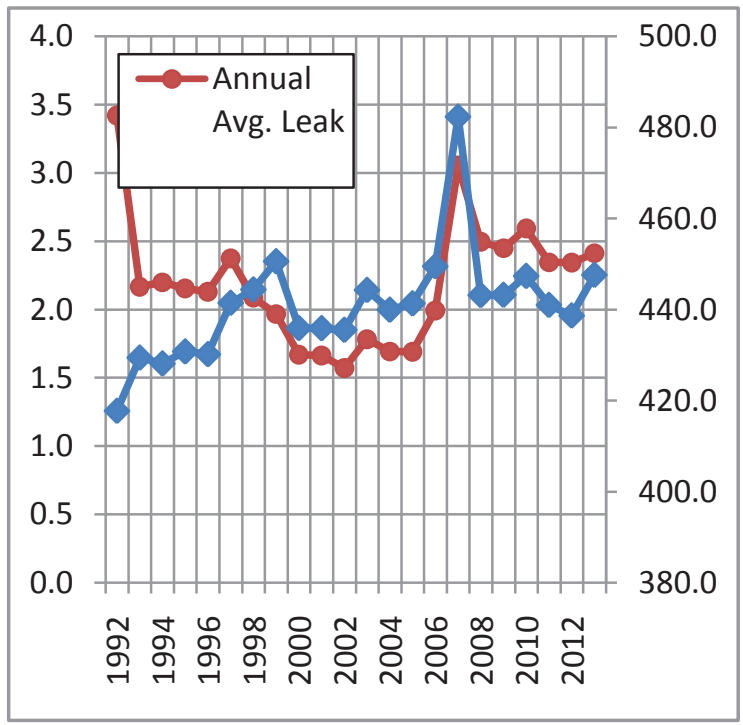

Figure 4- Behaviour of Leak \& Reservoir Water Levels (1992-2013)

Source: Author prepared from Samanalawewa Dam Monitoring Data (1992-2013) -CEB
According to Laksiri et al, 2005, a number of sinkholes had been found in an area far away from the areas under consideration. Preliminary studies had indicated a connection between these sinkholes and the main leakage. Detailed studies are underway to investigate the extent of the ingress areas to assist in planning suitable remedial measures. Because of the complex geological conditions caused by karst in the area of the site, the exact mechanism of leakage could not be established, preventing successful remediation.

\subsection{Perception - Theory}

According to Wehmeier and Ashby (2000) in the Oxford Advance Learners Dictionary the word 'Perception' is defined as "the way you notice the things, especially with the senses". However according to Schwarz (1994) in the Chambers Dictionary the word 'Perception' is defined as "the act or power of perceiving".

Schiffman and Kanuk (2007) have defined 'Perception' as the process by which an individual selects, organizes and interprets stimuli in to any of the senses. They also describe it as "how we see the world around us". Two individuals may be exposed to the same stimuli under the same apparent conditions, but how each person recognizes, selects, organizes and interprets these stimuli is a highly personalized process based on each person's own needs, values and expectations.

Berelson and Steiner (1964) as cited by Willium and Kincide (1885) define perception as a more complex process by which people select, organize and interpret sensory stimulations into a meaningful and coherent picture of the world.

Wikipedia (2013) defines 'Perception' as the process by which individuals select, organize, and interpret the input from their senses to give meaning and order to the world around them. The components of perception include the perceiver, target of perception, and the situation. Factors that influence the perceiver are as follows: 
- Schema: Organization and interpretation of information based on past experience and knowledge

- Motivational state: Needs, values, and desires of a perceiver at the time of perception

- Mood: Emotions of the perceiver at the time of perception

Factors that influence the target are as follows:

- Ambiguity: A lack of clarity. If ambiguity increases, the perceiver may find it harder to form an accurate perception

- Social Status: A person's real or perceived position in society or in an organization

- Impression Management: An attempt to control the perceptions or impressions of others. Targets are likely to use impression management tactics when interacting with perceivers who have power over them. Several impression management tactics include behavioural matching between the target of perception and the perceiver, selfpromotion (presenting one's self in a positive light), conforming to situational norms, appreciating others, or being consistent.

Based on all of the above, 'Perception' can be defined as the process by which stakeholders select, organize and interpret their sensory stimulations into a meaningful and coherent picture of the crisis of the water leakage of the Samanalawewa dam. This is used as the operational definition throughout this management case study.

\subsection{Perception Management - Theory}

According to the US Department of Defence (2001), actions to convey and/or deny selected information and indicators to foreign audiences to influence their emotions, motives, and objective reasoning as well as to intelligence systems and leaders to influence official estimates, ultimately result in foreign behaviors and official actions favourable to the originator's objectives. In various ways, perception management combines truth projection, operations security, cover and deception, and psychological operations.

$\mathrm{Ki}$ and Hon (2011) have stated that the relationship among relationship perception, attitude and behavior can be shown in a standard model as indicated below (Figure 4).

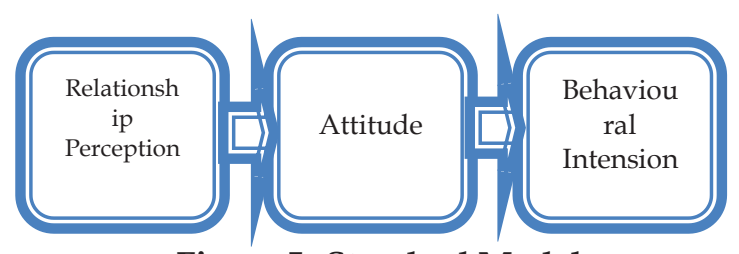

Figure 5- Standard Model

\section{Source : Author prepared from Ki and Hon (2011)}

$\mathrm{Ki}$ and Hon(2007a) as cited in $\mathrm{Ki}$ and Hon (2011) have evaluated the relationship between a university and its students to explore a casual model linking a public relationship perception, attitude towards the organization, and behavioural intention using a standard hierarchy of effect model (Perception $\rightarrow$ Attitude $\rightarrow$ Behavior). Also Hon and Grunig (1999) as cited in $\mathrm{Ki}$ and Hon (2011) have proposed six indices, viz., thrust, control maturity, commitment, satisfaction, communal and exchange. Ki and Hon (2007) have found that the students' relational perceptions of satisfaction and control maturity were significant predictors of attitudes, which in turn influence behavioural intensions.

Diener et al. (2003) as cited in Hellen and Sarkjavi (2011) have said that in the research stream called positive psychology, happiness has been conceptualized as a relatively stable perception of happiness one has towards one's life.

Happiness can be expected to influence the mood and perceptions of service quality, trust and outcome in adverse services for two main reasons. Firstly, because happy individuals are more inclined to experience positive affective states (Lyubomirsky et al., 2005a; Schimmack and Diener, 1997 as cited in Hellen and 
Sarkjavi, 2011) as they can be expected to be more inclined to experience positive affective states in service situations. Secondly, several studies have shown that happy and unhappy people perceive, interpret, evaluate and think about the same events differently, and in a manner consistent with and supportive of their level of happiness (Lyubomirsky et al., 2001; Lyubomirsky and Ross, 1997; Lyubomirsky and Tucker, 1998 as cited in Hellen and Sarkjavi, 2011).

\section{Case Framework \& Methodology}

\subsection{Case Framework}

The case framework consists of four key elements (variables) in sequential manner. In case framework, perception management is the dependent variable and CSR Projects, plant and occupational safety and productivity are independent variables. Case framework is indicated in Figure 5 below.

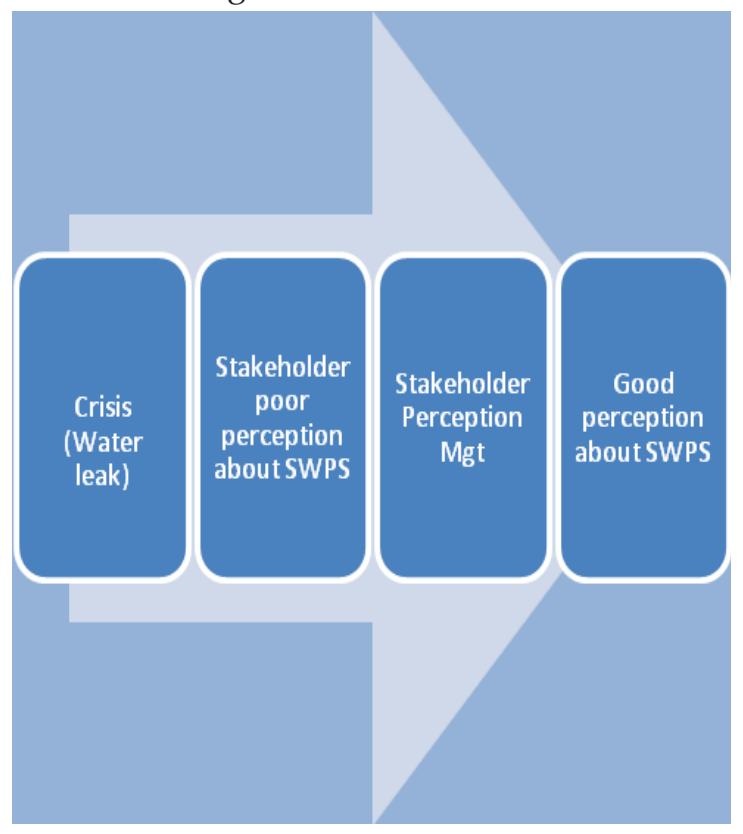

Figure 6 - Case Framework

Source: Author

\subsection{Stakeholders of SWPS}

SHEP is a multipurpose project. Water stored in the Samanalawewa reservoir is not only for power generation but also for several other purposes Compared to power generation, higher priority is given for issuing water downstream for irrigation, household use and ecological system balancing

The power generated in the SWPS is dispatched by the System Control Centre (SCC) of the CEB according to the system demand. Although it is the SCC that decides on the amount of power to be dispatched from the power station, the end user is the general public in Sri Lanka. SWPS, dam and its related other premises/sites together employ about 150 employees for various duties from both the CEB and hired from outside. Considering the facts mentioned, the stakeholders of the Samanalawewa Power Station, could be depicted for this management case study as shown in Figure 7.

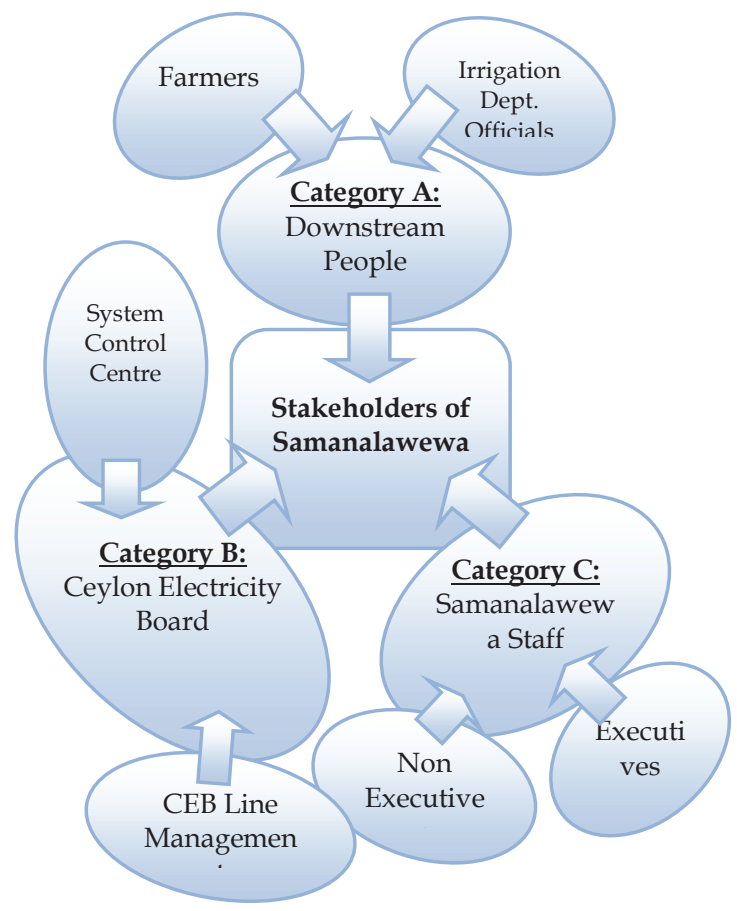

Figure 7 - Stakeholders of Samanalawewa

Source: Author

\subsection{Methodology}

This research which was originally planned to complete within a one-year period took $1 \frac{1}{2}$ years to complete. The Case Study Method was used especially considering the long time span of the issue. In-Depth Interviews and Focus Group Discussions were used mainly to collect qualitative data for proving the case framework. 


\section{Data Collection and Analysis}

Documentation, archival records, in-depth interviews and focus group discussions were used for the data collection.

Documents and reports available with the stakeholders and public sources including the internet were used. Since the case had to be spread over a period of twenty years, access to the data sources was limited.

Table 2 - In-depth Interviews

\begin{tabular}{|c|c|c|c|}
\hline No. & $\begin{array}{c}\text { Ref. } \\
\text { No. }\end{array}$ & $\begin{array}{c}\text { Stakeholder } \\
\text { Category }\end{array}$ & $\begin{array}{c}\text { Stakehold } \\
\text { er Sub } \\
\text { Category }\end{array}$ \\
\hline 1 & $\begin{array}{c}\text { FGD/A } \\
/ 1\end{array}$ & $\begin{array}{c}\text { Downstream } \\
\text { People }\end{array}$ & Farmers \\
\hline 2 & $\begin{array}{c}\text { FGD/C } \\
/ 1\end{array}$ & $\begin{array}{c}\text { Staff of the } \\
\text { Samanala } \\
\text { Wewa Power } \\
\text { station }\end{array}$ & $\begin{array}{c}\text { Non } \\
\text { Executive } \\
\mathrm{s}\end{array}$ \\
\hline
\end{tabular}

The interview guides were prepared targeting three main categories (A, B \& C) of stakeholders' as depicted in Figure 7. The questionnaires comprised of both open ended questions and close ended questions. A balance mix of questions was used to avoid descriptive answers, because the latter could

create difficulties in analysing the data.

Nine in-depth interviews and two focus group discussions, covering all three stakeholder categories were conducted (Table $02 \& 03$ ). Separate interview/discussion guides were used for all the interviews and discussions. All the interviews/discussions were recorded using a Transcend MP330 audio recorder.

The interview with each individual which was recorded was written down and illustrated in such a manner that it unfolded the events around the developed thematic framework. That helped to understand the connection between the poor perception after the crisis and the good perception after perception management.

Qualitative analysis was done based on the data, information and facts obtained from the data collected.

Table 3 - Focus Group Discussion

\begin{tabular}{|c|c|c|}
\hline No. & Ref. No. & Stakeholder Category \\
\hline 1 & $\begin{array}{l}\text { IDI/A/ } \\
1\end{array}$ & \multirow{3}{*}{$\begin{array}{l}\text { Downstream People - } \\
\text { Farmers }\end{array}$} \\
\hline 2 & $\begin{array}{l}\text { IDI/A/ } \\
2\end{array}$ & \\
\hline 3 & $\begin{array}{l}\text { IDI/A/ } \\
3\end{array}$ & \\
\hline 4 & IDI/B/1 & \multirow{2}{*}{$\begin{array}{l}\text { Staff of the System Control } \\
\text { Centre \& CEB Management }\end{array}$} \\
\hline 5 & $\mathrm{IDI} / \mathrm{B} / 2$ & \\
\hline 6 & IDI/C/1 & \multirow{4}{*}{$\begin{array}{l}\text { Staff of the Samanalawewa } \\
\text { Power station }\end{array}$} \\
\hline 7 & $\mathrm{IDI} / \mathrm{C} / 2$ & \\
\hline 8 & $\mathrm{IDI} / \mathrm{C} / 3$ & \\
\hline 9 & $\mathrm{IDI} / \mathrm{C} / 4$ & \\
\hline
\end{tabular}

\section{Results and Discussion}

From the data analysis, it was verified and proved that the sequence of variables in the case framework was correct. The important elements of the case framework are discussed below.

\subsection{Crisis and Post Crisis Situation}

After the completion of the cut-off works on the right bank in October 1992 and while the water was filling up the reservoir, a massive water leakage which was unexpected had occurred about $250 \mathrm{~m}$ downstream of the dam due to some weak subsurface soil formation ( Molle et al., 2005).

As a measure against the water leakage from the right bank of the dam, work to cut off the right bank (curtain grouting) was carried out utilizing the funds provided by the loan received under Phase III and wet blanketing was performed under the project for remedial work. The amount of water leakage when the reservoir was full and before the remedial work commenced decreased from $2.8 \mathrm{~m}^{3}$ per second to $2.2 \mathrm{~m}^{3}$ per second. Since then until 2006, the amount of water leakage had been stable at 
around 1.5 to $2 \mathrm{~m}^{3} / \mathrm{s}$ depending on the reservoir water level. After the $2^{\text {nd }}$ blast of the leak in 2006 it is now operating at an average rate of $2.4 \mathrm{~m}^{3} / \mathrm{s}$.

However a water leakage like this has not happened in Sri Lanka before this and therefore this particular water leakage resulted in a very poor public perception of the Project The sequence of events also resulted in a post crisis situation among the stakeholders.

\subsection{Stakeholders Poor Perception}

This situation has been identified as a crisis and a post crisis situation by the stakeholders of the SWPS. Especially the farmers in the downstream (Kaltota Irrigation Scheme) protested against the operation of the power station saying that the water leakage would be a threat for their livelihood. That situation was exaggerated by the media which might have been supported by regional politicians and farmer organizations.

However, on December 3, 2006 (2nd blast), the amount of water leakage surged to over $5 \mathrm{~m}^{3} / \mathrm{s}$. After that, as the groundwater level in the right bank and the reservoir water level lowered, the amount of water leakage decreased to $2.9 \mathrm{~m}^{3}$ per second (as of March 12, 2007), which was still higher than the leakage experienced prior to the implementation of the remedial work. Therefore, it can be said that the purpose of the remedial work was fulfilled until December 2006. However, the remedial work is no longer being carried out as intended.

The main reasons for the stakeholder poor perception were found to be the risk of dam breach, difficulty in finding a permanent solution to the leak, waste of water (money) due to the uncontrollable water leakage, poor reliability due to the leak, lower availability due to the water leakage, public/media pressure to the management, and the additional costs \& time to find a solution to the leak .

\subsection{Perception Management}

Stakeholder perception management was mainly achieved through CSR projects, plant and occupational safety and productivity improvement. They were identified as independent variables to the case framework established for perception management.

\subsubsection{Corporate Social Responsibility Projects}

Towards winning the hearts and minds of the public living downstream, the power station carried out a large number of CSR activities. They were grouped into four categories as mentioned below.

\section{i. General}

- $\quad$ Truth Projection - CEB provided bus service to the public for site visits

- Establishment of an emergency communication system

- Donations to affected people - facility improvement in resettlements

\section{ii. Agriculture \& Irrigation}

- Technical directives to farmer organizations

$>$ Introduction of new cultivation methods (Sri Method)

$>$ Introduction of new varieties of paddy (Nawakekulan paddy)

$>$ Irrigation system development (Field channels \& culverts)

- Provision of agricultural machines and tractors to the farmers free of charge

\section{iii. Health}

- Assistance extended to local hospitals

- Provision of a free ambulance service to the villagers in emergencies

\section{iv. Education}

- Assistance extended to school education donations \& scholarships

- Establishment of a pre-school

\subsection{2}

\section{Plant and Occupational Safety Improvement}

To make the power station a success, it was paramount to improve the reliability of the 
plant and its machinery including the massive civil structures such as the dam, spillway gates and the tunnel. The improvements proposed were categorized into two categories as mentioned below.

\section{i. Safety of the Dam -controlling Right Bank Water Leakage}

- $\quad$ Right bank cut off work (Grout Curtain)

- Wet Blanketing

- Continuous dam monitoring by dedicated staff employed at the site

- Application of technology to eliminate risk situations

ii. Effective \& Efficient Plant/Equipment Maintenance and Occupational Safety

- Improved operation and maintenance practices

- Good housekeeping practices

- Establishment of occupational safety standards at the premises

- $\quad$ Training of staff

Some achievements of the SWPS in occupational safety which are tabulated below show their effectiveness.

\subsubsection{Productivity improvements}

The quality improvement at the SWPS made a huge change in the stakeholder perception management. The key items identified for productivity improvements were the implementation of 5S good housekeeping practices as a productivity improving tool, implementation of ISO Quality Management Standards and ISO Environmental Management Standards. The map of the perception management is mentioned in Appendix I.

\subsection{Stakeholder Good Perception about the SWPS}

Farmers' poor perception of the power station improved mainly because of the CSR projects. The conflicts between the farmers and the power station were managed by releasing the optimum quantity of water to irrigation schemes (Mainly Kaltota Irrigation Scheme).

The poor perception of the SCC of CEB is mainly because of the operational unreliability of the plant. It was managed by improving the operation and maintenance of the plant and the machinery by ensuring quality standards.

As a result of the productivity improvements there were key performance improvements such as the high annual generation (an average of $267 \mathrm{GWh}$ which is $67 \%$ of anticipated generation), lower annual average forced outages (3.25\%) and high plant availability (Avg. 91\%).

The SWPS was also identified to be the first in the CEB to implement productivity enhancement. Even Lanka Electricity Company (LECO) obtained ISO certification after SWPS. Later several other branches/units (Meter Testing Laboratory, Kuliyapititya in 2010 and Technical Training Centre, Piliyandala in 2011) followed SWPS and obtained ISO certification. This can be identified as a paradigm shift in the CEB.

Table 4 - Safety Achievements

\begin{tabular}{|l|l|l|}
\hline Year & \multicolumn{1}{|c|}{ Award description } & Rank \\
\hline 2999 & $\begin{array}{l}\text { National Safety Award/ } \\
\text { Sabaragamuwa Province }\end{array}$ & Winner \\
\hline 2001 & $\begin{array}{l}\text { National Safety Award - } \\
\text { Sabaragamuwa Province }\end{array}$ & Winner \\
\hline 2003 & $\begin{array}{l}\text { National Safety Award - All } \\
\text { Island - Small Scale }\end{array}$ & $\begin{array}{l}\text { Runner- } \\
\text { up }\end{array}$ \\
\hline 2004 & $\begin{array}{l}\text { Industrial Safety Award - } \\
\text { All Island - Small Scale }\end{array}$ & Winner \\
\hline 2006 & $\begin{array}{l}\text { Industrial Safety Award - } \\
\text { All Island - Small Scale }\end{array}$ & Winner \\
\hline
\end{tabular}

Source: Author created from SWPS- CEB data

Since management had a good perception about the performance and other achievements of the SWPS, it was opened to the public by the 
management after the north and east war ended in 2009.

\section{Conclusions}

The poor perception that resulted from the crisis and the post crisis situation that arose at Samanalawewa, due to the water leakage from the right abutment of the Samanalawewa dam have been successfully managed during the last twenty years (1992-2012) by the SWPS. Finding a permanent solution to the water leakage, continuous productivity improvement, implementation of a knowledge management system and the training of the staff are the measures that can be recommended to enable the SWPS to continue to maintain its good perception in the future. The benchmarking of the SWPS may also enhance the performance of other units/branches of the CEB as well as other organizations. This perception management case study can be considered as a very good lesson for the CEB for managing its future projects.

\section{References}

1. Ceylon Electricity Board (2011). Annual Report, Colombo.

2. Ceylon Electricity Board (2012). Statistical digest, Colombo.

3. Hohenemser, C and Renn, O. (2010). Shifting public perceptions on nuclear risk, Environment, Vol. 3, No. 3in public health. Health Journal Vol.5, No.3, 440-444

4. Laksiri, K. Gunathilake, \& J. Iwao, Y.A (2005) Case Study of the Samanalawewa Reservoir on the Walawe River in an Area of Karst in Sri Lanka

5. Laksiri, K. Gunathilake, \& J. Iwao, Y.A (2005) Case Study of the Samanalawewa Reservoir on the Walawe River in an Area of Karst in Sri Lanka

6. Mollle, F. Jayakody, P. Ariyarathna, R. and Somathilake, H.S. Balancing Irrigation and Hydropower: A Case Study from Southern Sri Lanka

7. Organizational Reform in Sri Lankan Public Sector; Developing a process re-engineering framework, (2011). Gunawardhana, H. and Dharmasiri, A.S. Sri Lanka Journal of Management Vol. 16, 2011Vol. 16,

8. Rathnasiri, J. (2012 August 26). Samanalawewa leak - Engineering blunder or a blessing? Retrieved from http://www.island.lk/index.php?page_cat $=$ article-details $\&$ page $=$ articledetails\&code_title $=60107$

9. Realise full potential of paddy plant - Sri Method of paddy cultivation, Watershed Support Services and Activities Network, Sekunderabad 2006

10. Samanalawewa Hydro Power Station, (2009) Quality Manual, Balangoda

11. Schiffman, L. G. \& Kanuk, L. L. (1999). Consumer Behavior. New Delhi: Prentice Hall of India Private Limited.

12. Schwarz, C. (Ed.), (1994). The Chambers Dictionary. Edinburgh: Chambers Harrap Publishers Ltd.

13. Shindo, H. (2007), Post Project Evaluation Report - Samanalawewa Hydroelectric Project (I) (II) (II) E Reservoir Remedial Works

14. Wehmeier, S., \& Ashby, M. (Eds.), (2000). Oxford Advance Learners Dictionary. United Kingdom: Oxford University Press.

15. Yin. R.K., (2009). Case Study Research design and Methods. London: SAGE Ltd 


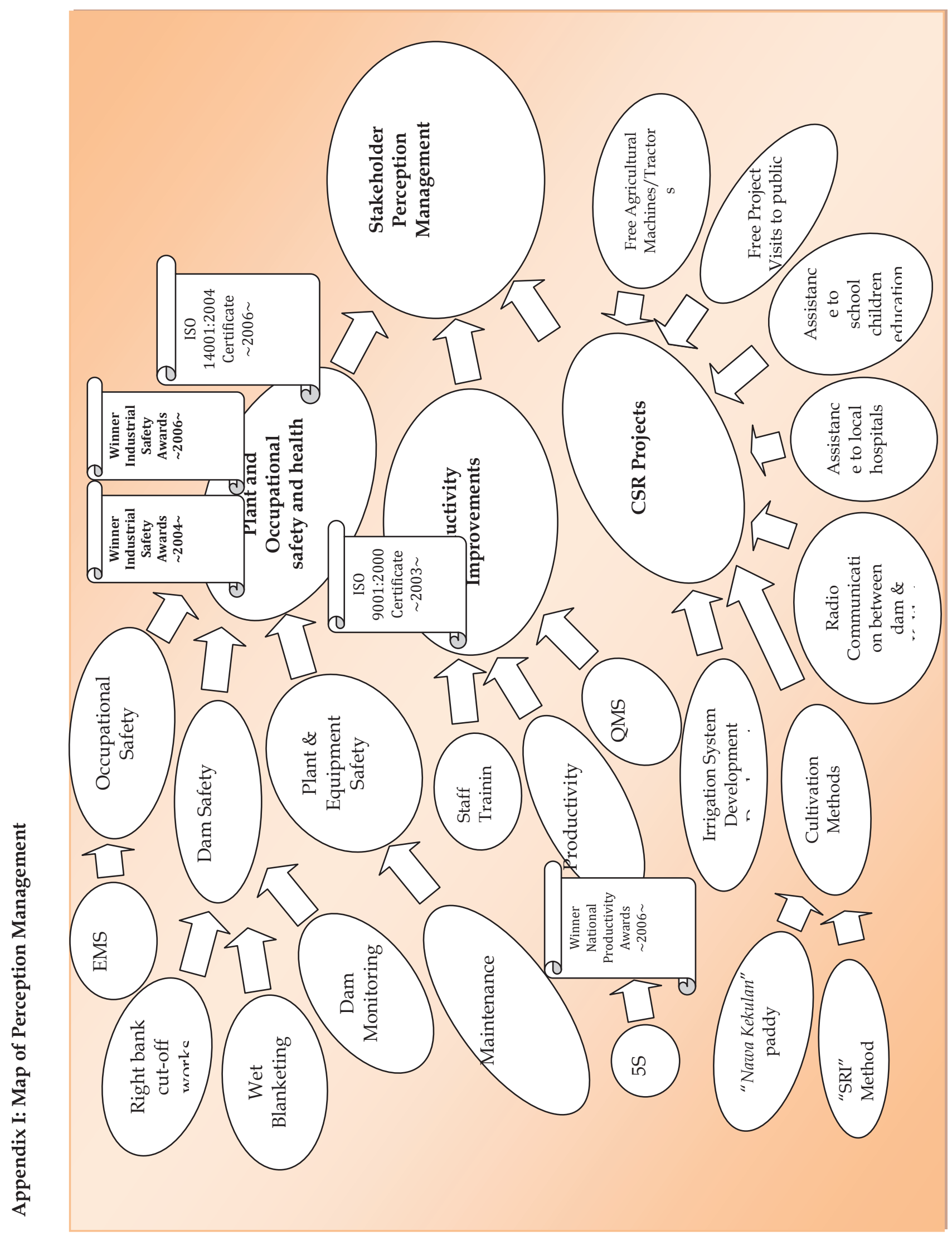

